\title{
Pengaruh yogurt sinbiotik pisang terhadap kadar glukosa dan insulin tikus sindrom metabolik
}

Effect of synbiotic yoghurt banana on blood glucose and insulin levels in metabolic syndrome rats

Fiqhi Cahyaningrum Rahmawati ${ }^{1}$, Kis Djamiatun ${ }^{2}$, Nyoman Suci ${ }^{3}$

${ }^{1}$ Program Studi Magister Ilmu Gizi, Fakultas Kedokteran Universitas Diponegoro
${ }^{2}$ Bagian Biomedik, Fakultas Kedokteran Universitas Diponegoro
${ }^{3}$ Bagian Patologi Klinik, Fakultas Kedokteran Universitas Diponegoro / Rumah Sakit Umum Pusat Dr. Karyadi

\begin{abstract}
Background: The metabolic syndrome often begins with insulin resistance characterized by hyperinsulinemia and hyperglycemia. Synbiotic yoghurt tanduk banana contains probiotic and prebiotic FOS can improve insulin resistance in metabolic syndrome. Objective: To prove the effect of synbiotic yoghurt tanduk banana can reduce blood glucose levels and insulin levels in metabolic syndrome rats. Method: True-experimental study with randomized controlled group pre-post test design in male wistar rats. Eighteen samples were induced to become metabolic syndrome with high fat fructose diet for 2 weeks and they were divided into 3 groups: control (K) was given standard diet, treatment group 1 (P1), and treatment group 2 (P2) were given sinbiotic yoghurt tanduk banana dose of $0.009 \mathrm{ml} / \mathrm{g}$ body weight $(\mathrm{BW}) /$ day and $0.018 \mathrm{ml} / \mathrm{g}$ BW/day for 2 weeks. Results: The paired t-test showed there were differences of blood glucose levels and insulin levels before and after treatment in P2 group. The Kruskal Wallis test showed there were differences of mean blood glucose levels inter group after treatment ( $p<0.05)$. The One-way Anova test showed there were differences of mean insulin levels inter group after treatment $(p<0.05)$. Conclusion: Synbiotic yoghurt tanduk banana can reduce blood glucose levels and insulin levels in metabolic syndrome rat with effective dose is $0.018 \mathrm{ml} / \mathrm{grBW} / \mathrm{day}$.
\end{abstract}

KEYWORDS: blood glucose; insulin; metabolic syndrome; synbiotic yoghurt banana

\begin{abstract}
ABSTRAK
Latar belakang: Sindrom metabolik diawali dengan resistensi insulin yang ditandai dengan hiperinsulinemia dan hiperglikemia. Yogurt sinbiotik pisang tanduk mengandung probiotik dan prebiotik fruktooligosakarida (FOS) yang dapat memperbaiki resistensi insulin pada sindrom metabolik. Tujuan: Membuktikan pengaruh yogurt sinbiotik pisang tanduk dalam menurunkan kadar glukosa darah dan kadar insulin tikus sindrom metabolik. Metode: True-experimental dengan rancangan randomized controlled group pre-post test design pada tikus wistar jantan. Delapan belas tikus dibuat sindrom metabolik dengan high fat fructose diet selama 2 minggu dan dibagi menjadi 3 kelompok: kelompok kontrol (K) diberi pakan standar, kelompok perlakuan 1 (P1), dan kelompok perlakuan 2 (P2) diberi yogurt sinbiotik pisang tanduk dosis $0,009 \mathrm{ml} / \mathrm{g}$ berat badan (BB) tikus/hari dan $0,018 \mathrm{ml} / \mathrm{g}$ BB tikus/hari selama 2 minggu. Hasil: Uji beda paired t-test menunjukkan ada perbedaan kadar glukosa darah dan insulin sebelum dan setelah diberi perlakuan pada kelompok P2 ( $\mathrm{p}=0,000)$. Hasil uji Kruskal Wallis menunjukkan ada perbedaan selisih rerata kadar glukosa darah yang bermakna antarkelompok setelah perlakuan. Hasil uji One-way Anova menunjukkan ada perbedaan selisih rerata kadar insulin yang bermakna antarkelompok setelah perlakuan. Simpulan: Yogurt sinbiotik pisang tanduk terbukti dapat menurunkan kadar glukosa darah dan kadar insulin tikus sindrom metabolik dengan dosis yang paling efektif $0,018 \mathrm{ml} / \mathrm{g}$ BB tikus/hari.
\end{abstract}

KATA KUNCI: glukosa darah; insulin; sindrom metabolik; yogurt sinbiotik pisang

\section{PENDAHULUAN}

Sindrom metabolik adalah kumpulan dari berbagai faktor risiko termasuk obesitas sentral, dislipidemia (meningkatnya trigliserida dan menurunnya kolesterol HDL), hipertensi, dan peningkatan glukosa darah puasa yang ditandai dengan kenaikan risiko diabetes mellitus dan penyakit kardiovaskuler. Seseorang menderita sindrom metabolik jika mempunyai lebih dari atau sama dengan 3 dari 5 tanda dan gejala tersebut berdasarkan

Korespondensi: Fiqhi Cahyaningrum Rahmawati, Program Studi Magister Ilmu Gizi, Fakultas Kedokteran Universitas Diponegoro, J1. Dr.Sutomo No.18 Semarang, Jawa Tengah, Indonesia, e-mail: FiqhiCR_9@yahoo.com 
National Cholesterol Education Program (1). Populasi dewasa di dunia yang menderita sindrom metabolik berdasarkan International Diabetes Federation (IDF) yaitu $20-25 \%$ yaitu $8-24,2 \%$ pada populasi pria dan $7-46,5 \%$ pada populasi wanita (2).

Sindrom metabolik seringkali diawali dengan obesitas dan resistensi insulin. Saat obesitas, terjadi peningkatan asam lemak bebas di hati yang akan meningkatkan glukoneogenesis, meningkatkan produksi glukosa hati, dan meningkatkan resistensi insulin sehingga terjadi hiperinsulinemia. Resistensi insulin juga menyebabkan penyerapan glukosa dalam otot dan lemak berkurang dan menyebabkan produksi glukosa meningkat di dalam hati (3). Resistensi insulin adalah berkurangnya sensitivitas insulin di dalam otot, jaringan adiposa, dan sel hati (4). Resistensi insulin ditandai dengan keadaan hiperinsulinemia dan hiperglikemia (5).

Pengaturan diet dan perubahan gaya hidup dapat dilakukan untuk mencegah berkembangnya komplikasi dari sindrom metabolik. Konsumsi sinbiotik sebagai pangan fungsional juga dapat memberikan efek kesehatan yang baik. Sinbiotik atau yang disebut juga eubiotik merupakan kombinasi antara probiotik dan prebiotik. Keuntungan dari kombinasi ini adalah selain terdapat bakteri probiotik yang mempunyai efek kesehatan yang baik, juga terdapat prebiotik yang dapat menyediakan substrat spesifik untuk fermentasi sehingga mendorong pertumbuhan bakteri probiotik (efek bifidogenik) $(6,7)$.

Yogurt pisang tanduk (Musa paradisiaca fa. corniculata) merupakan yogurt sinbiotik. Probiotik dari yogurt berasal dari bakteri Lactobacillus bulgaricus dan Streptococcus thermopillus yang dapat memfermentasi susu. Prebiotik dalam yogurt berasal dari penambahan bahan makanan yang mengandung fruktooligosakarida (FOS) (8). Sumber pangan yang mengandung FOS relatif tinggi dan mudah ditemui di Indonesia adalah pisang (9). Pisang tanduk (Musa paradisiaca fa. corniculata) yang diolah dalam bentuk tepung mempunyai kandungan FOS sebesar 6,08\% (10). Bakteri asam laktat pada yogurt yang berguna untuk kesehatan dapat meningkat dengan penambahan prebiotik FOS sebesar $1 \%$. Penambahan prebiotik FOS yang berasal dari tepung pisang ke dalam yogurt juga dapat meningkatkan kandungan serat dalam yogurt sinbiotik yang berperan dalam menghambat penyerapan glukosa di dalam saluran pencernaan sehingga peningkatan kadar glukosa darah dapat ditekan (11).

Penelitian sebelumnya pada penderita diabetes mellitus dengan pemberian minuman sinbiotik sebanyak $200 \mathrm{ml}$ dapat menurunkan kadar glukosa darah dan meningkatkan kadar high density lipoprotein (HDL) (12). Efek probiotik dari sinbiotik pada metabolisme glukosa dan resistensi insulin kemungkinan besar karena sifatnya yang dapat memodulasi sistem imun dan kesehatan saluran pencernaan (13). Prebiotik FOS tidak dapat dicerna dalam saluran percenaan dan difermentasi mikroflora kolon menghasilkan short chain fatty acid (SCFA) yaitu asam propionat yang dapat menghambat glukoneogenesis di hati sehingga dapat menekan produksi glukosa dan menurunkan resistensi insulin $(14,15)$. Berdasarkan penelitian sejenis dengan judul pengaruh pemberian yogurt sinbiotik tepung pisang tanduk terhadap profil lipid tikus sindrom metabolik menunjukkan pemberian yogurt sinbiotik tepung pisang tanduk selama 2 minggu dengan dosis $0,009 \mathrm{ml} / \mathrm{g}$ berat badn (BB) tikus/hari dan 0,018 ml/g BB tikus/hari dapat memperbaiki profil lipid tikus wistar jantan yang dikondisikan sindrom metabolik (16). Penelitian tersebut tidak dilakukan analisis terhadap kadar glukosa darah dan insulin sebelum dan setelah perlakuan, sementara perubahan kedua parameter ini merupakan tanda terjadinya resistensi insulin yang biasanya terjadi pada sindrom metabolik.

Berdasarkan bukti-bukti tersebut maka perlu dilakukan penelitian pendahuluan pada hewan coba untuk membuktikan pemberian yogurt pisang tanduk terhadap penurunan kadar glukosa darah dan insulin tikus wistar jantan yang dikondisikan sindrom metabolik sebelum produk yogurt sinbiotik pisang tanduk ini dapat digunakan di masyarakat sebagai diet alternatif pada sindrom metabolik. Penelitian ini bertujuan membuktikan pengaruh yogurt sinbiotik pisang tanduk dalam menurunkan kadar glukosa dan insulin tikus sindrom metabolik dengan dosis $0,009 \mathrm{ml} / \mathrm{g}$ BB tikus/hari dan $0,018 \mathrm{ml} / \mathrm{g}$ BB tikus/hari selama $2 \mathrm{minggu}$.

\section{BAHAN DAN METODE}

Jenis penelitian ini adalah true-experimental dengan rancangan randomized controlled group pre-post 
test design. Variabel bebas dalam penelitian ini adalah pemberian yogurt sinbiotik pisang tanduk dan variabel terikatnya adalah kadar glukosa darah puasa dan kadar insulin puasa. Sampel penelitian yang digunakan adalah tikus wistar jantan usia 8-12 minggu, kondisi dan anatomi sehat serta berat badan tikus 150-200 g yang diperoleh dari Laboratorium Pusat Studi Pangan dan Gizi, Universitas Gajah Mada Yogyakarta. Pemeliharaan hewan coba tikus wistar jantan, pembuatan tepung pisang tanduk dan yogurt sinbiotik pisang tanduk, serta pemeriksaan sampel darah tikus dilakukan di Laboratorium Pusat Studi Pangan dan Gizi, Universitas Gajah Mada Yogyakarta pada bulan Desember 2016-Januari 2017. Pemeriksaan sampel darah berupa serum meliputi pemeriksaan kadar glukosa darah puasa dilakukan 3 kali (awal, sebelum, dan sesudah perlakuan) dan pemeriksaan kadar insulin puasa dilakukan 2 kali (sebelum dan sesudah perlakuan). Kadar glukosa darah diukur menggunakan metode GOD-PAP dan kadar insulin menggunakan metode ELISA dengan gelombang pembacaan $450 \mathrm{~nm}$.

Tikus wistar jantan yang digunakan berjumlah 18 ekor untuk 3 kelompok (sesuai WHO mengenai sampel hewan coba setiap kelompok minimal 5 ekor dan ditambah estimasi drop out 1 ekor untuk setiap kelompok) (17). Hewan coba diaklimatisasi selama 7 hari dengan kandang individual dan diberikan pakan standar berupa comfeed II sebanyak 20 g/ 200 g BB tikus per hari dan air minum ad libitum (18). Pakan standar berupa pakan ayam comfeed II terdiri dari protein kasar 19\%; lemak kasar 5\%; kadar air 12\%; serat kasar 4,5\%; abu 6,5\%; kalsium $0,9-1,2 \%$; dan fosfor $0,7-0,9 \%$. Selanjutnya, tikus dipuasakan 8-10 jam dan diambil darahnya sebanyak $2 \mathrm{ml}$ melalui pleksus retroorbitalis untuk pemeriksaan kadar glukosa darah puasa awal. Setelah fase adaptasi ini, semua kelompok diberi pakan standar dan pakan tinggi lemak tinggi fruktosa selama 2 minggu untuk mengkondisikan tikus menjadi sindrom metabolik. Pakan tinggi lemak tinggi fruktosa berupa campuran dari minyak babi sebanyak $2 \mathrm{ml} / 200 \mathrm{~g}$ BB tikus; kuning telur $1 \mathrm{ml} /$ $200 \mathrm{~g}$ BB tikus; dan fruktosa $1 \mathrm{ml} / 200 \mathrm{~g}$ BB tikus yang diberikan melalui sonde lambung (19). Tikus selanjutnya dipuasakan 8-10 jam dan diambil darahnya sebanyak $2 \mathrm{ml}$ melalui pleksus retroorbitalis untuk pemeriksaan kadar glukosa darah, kadar insulin, kadar trigliserida, dan kadar HDL untuk mengetahui kondisi sindrom metabolik sudah tercapai. Sebanyak 18 ekor tikus dibagi secara acak menjadi 3 kelompok, masing-masing kelompok terdiri dari 6 ekor tikus, yaitu kelompok kontrol (K) yang diberi pakan standar; kelompok perlakuan 1 (P1) yang diberi pakan standar dan yogurt sinbiotik tepung pisang tanduk dosis 0,009 ml/g BB tikus/hari; dan kelompok perlakuan 2 (P2) yang diberi pakan standar dan yogurt sinbiotik tepung pisang tanduk dosis $0,018 \mathrm{ml} / \mathrm{g}$ BB tikus/ hari selama 2 minggu. Selanjutnya, tikus dipuasakan 8-10 jam dan diambil darahnya sebanyak $2 \mathrm{ml}$ melalui pleksus retroorbitalis untuk pemeriksaan kadar glukosa darah puasa dan kadar insulin puasa sesudah perlakuan. Penimbangan berat badan dilakukan setiap 1 minggu sekali.

Tepung pisang tanduk dibuat dari pisang tanduk mengkal (3/4 matang) yang direbus selama 15 menit setelah dilepas kulitnya dan dicuci. Pisang kemudian dikupas, diiris tipis setebal 0,25-0,75 cm. Irisan pisang dikeringkan menggunakan oven dengan suhu $75^{\circ} \mathrm{C}$ selama 8 jam lalu dihaluskan dengan alat penggiling (grinder) dan diayak menggunakan ayakan 80 mesh. Proses pembuatan yogurt sinbiotik dengan mencampur susu segar komersial yang sudah dipasteurisasi dengan tabel informasi nilai gizi mengandung 0 gram lemak dan susu skim bubuk dengan tabel informasi nilai gizi mengandung 0 gram lemak dengan tepung pisang tanduk. Campuran susu dan tepung pisang tanduk selanjutnya dihomogenisasi kemudian dipasteurisasi pada suhu $90^{\circ} \mathrm{C}$ selama 5 menit dan didinginkan hingga suhu $42^{\circ} \mathrm{C}$. Langkah selanjutnya, ditambahkan inokulum Lactobacillus bulgaricus dan Streptococcus thermophilus yang telah ditumbuhkan di media susu dengan perbandingan 1:1 (v/v) dan diaduk hingga rata. Inkubasi dilakukan dalam inkubator dengan suhu $42^{\circ} \mathrm{C}$ hingga mencapai $\mathrm{pH} 4,6$. Setelah itu, disimpan di lemari pendingin pada suhu $4^{\circ} \mathrm{C}$. Pembuatan yogurt dilakukan sebanyak 3 kali selama 2 minggu perlakuan.

Penelitian ini telah memperoleh persetujuan ethical clearance dari Komisi Etik Penelitian Kesehatan (KEPK) Fakultas Kedokteran Universitas Diponegoro / Rumah Sakit Umum Pusat dr. Kariadi No.47/EC/FK-RSDK/ II/2017. Uji normalitas data dengan uji Shapiro-Wilk. Uji beda sebelum dan sesudah perlakuan menggunakan uji paired t-test (distribusi data normal). Analisis perbedaan 
pengaruh dari ketiga kelompok perlakuan menggunakan uji statistik parametrik One-way ANOVA untuk data terdistribusi normal dan dilakukan uji statistik non parametrik Kruskal Wallis untuk data terdistribusi tidak normal.

\section{HASIL}

\section{Berat badan tikus}

Penimbangan berat badan dilakukan setiap 1 minggu sekali untuk menentukan jumlah pakan standar, pakan tinggi lemak tinggi fruktosa (minggu ke-1 dan 2), dan dosis yogurt sinbiotik pisang tanduk yang akan diberikan (minggu ke-3 dan 4). Hasil uji homogenitas varians selisih rerata berat badan sebelum dan setelah pemberian pakan tinggi lemak tinggi fruktosa diperoleh nilai $p<0,05$ yang artinya varians data tidak sama sehingga perbedaan perubahan berat badan antarkelompok dianalisis menggunakan uji Kruskal Wallis, didapatkan hasil bahwa tidak ada perbedaan perubahan berat badan tikus antarkelompok setelah pemberian pakan tinggi lemak dan fruktosa $(p>0,05)$. Perbedaan perubahan berat badan antar kelompok setelah pemberian yogurt sinbiotik pisang tanduk dianalisis menggunakan uji Kruskal Wallis, didapatkan hasil bahwa terdapat perbedaan perubahan berat badan tikus antara kelompok kontrol, kelompok perlakuan 1, dan kelompok perlakuan $2(\mathrm{p}=0,000)$. Peningkatan rerata berat badan terbesar setelah perlakuan terlihat pada kelompok kontrol. Peningkatan berat badan terkecil setelah perlakuan terlihat pada kelompok perlakuan 2 dengan dosis yogurt sinbiotik 0,018 ml/g BB tikus/hari. Tabel 1 menunjukkan perubahan berat badan tikus setelah aklimatisasi, setelah pemberian high fat fructose diet (HFFD), dan setelah pemberian yogurt sinbiotik pisang tanduk.

\section{Pengkondisian tikus sindrom metabolik}

Nilai normal kadar glukosa darah puasa tikus sebesar 50-109 mg/dl, nilai normal kadar trigliserida puasa tikus 20-114 mg/dl, dan nilai normal kadar HDL puasa tikus yaitu kurang dari $35 \mathrm{mg} / \mathrm{dL}$. Pemberian pakan tinggi lemak tinggi fruktosa menyebabkan tikus percobaan mengalami hiperglikemia (rerata kadar glukosa puasa $129,31 \pm 0,54 \mathrm{mg} / \mathrm{dl}$ ), hipertrigliseridemia (rerata kadar trigliserida $145,32 \pm 3,82 \mathrm{mg} / \mathrm{dl}$ ), dan penurunan kadar kolesterol HDL (rerata kadar kolesterol HDL 25, 10 $\pm 1,65 \mathrm{mg} / \mathrm{dl}$ ) sehingga kondisi sindrom metabolik telah tercapai.

\section{Rerata kadar glukosa sebelum dan sesudah pemberian high fat fructose diet}

Rerata kadar glukosa darah tikus pada akhir tahap aklimatisasi dan sesudah pemberian pakan HFFD setiap kelompok dapat dilihat pada Tabel 2. Setelah pemberian HFFD, pada ketiga kelompok tikus menunjukkan

Tabel 1. Perubahan berat badan tikus

\begin{tabular}{ccccccc}
\hline Kelompok & $\mathbf{n}$ & $\begin{array}{c}\text { Aklimatisasi } \\
\text { Rerata } \pm \text { SB } \\
(\mathbf{g})\end{array}$ & $\begin{array}{c}\text { HFFD }^{1} \\
\text { Rerata } \pm \text { SB } \\
(\mathbf{g})\end{array}$ & $\begin{array}{c}\text { Yogurt } \\
\text { Rerata } \pm \text { SB } \\
(\mathbf{g})\end{array}$ & $\begin{array}{c}\text { p } \\
\text { Aklimatisasi- } \\
\text { HFFD }^{1}\end{array}$ & $\begin{array}{c}\text { p } \\
\text { HFFD }^{1-} \\
\text { Yogurt }\end{array}$ \\
\hline K & 6 & $186,67 \pm 5,79$ & $205,50 \pm 5,24$ & $229,00 \pm 5,37$ & & \\
P1 & 6 & $185,50 \pm 6,72$ & $204,50 \pm 7,40$ & $219,67 \pm 7,26$ & $0,685^{2}$ & $0,000^{2}$ \\
P2 & 6 & $185,00 \pm 10,02$ & $203,50 \pm 10,78$ & $212,33 \pm 10,39$ & & \\
\hline
\end{tabular}

${ }^{1} \mathrm{HFFD}=$ high fat fructose diet; ${ }^{2}$ Kruskal Wallis

Tabel 2. Rerata kadar glukosa darah sebelum dan sesudah pemberian HFFD selama 14 hari

\begin{tabular}{ccccccc}
\hline Kelompok & $\mathbf{n}$ & $\begin{array}{c}\text { Aklimatisasi } \\
\text { Rerata } \pm \mathbf{S B} \\
(\mathbf{m g} / \mathbf{d l})\end{array}$ & $\begin{array}{c}\text { HFFD }^{1} \\
\text { Rerata } \pm \mathbf{S B} \\
(\mathbf{m g} / \mathbf{d l})\end{array}$ & $\mathbf{p}^{2}$ & $\begin{array}{c}\Delta \text { Perubahan } \\
(\mathbf{m g} / \mathbf{d l})\end{array}$ & $\mathbf{p}^{3}$ \\
\hline $\mathrm{K}$ & 6 & $63,72 \pm 1,51$ & $129,69 \pm 2,60$ & 0,000 & $65,97 \pm 2,04(103,58 \%)$ & \\
$\mathrm{P} 1$ & 6 & $64,99 \pm 1,92$ & $128,23 \pm 1,86$ & 0,000 & $63,23 \pm 3,23(97,48 \%)$ & 0,066 \\
$\mathrm{P} 2$ & 6 & $62,83 \pm 1,53$ & $130,01 \pm 2,32$ & 0,000 & $67,19 \pm 2,81(107,05 \%)$ & \\
\hline
\end{tabular}

${ }^{1} \mathrm{HFFD}=$ high fat fructose diet; ${ }^{2}$ paired $t$-test $;{ }^{3}$ One-way ANOVA 
Tabel 3. Rerata kadar glukosa darah sebelum dan sesudah pemberian yogurt sinbiotik pisang tanduk selama 14 hari

\begin{tabular}{ccccccc}
\hline Kelompok & $\mathbf{n}$ & $\begin{array}{c}\text { HFFD }^{\mathbf{1}} \\
\text { Rerata } \pm \text { SB } \\
(\mathbf{m g} / \mathbf{d l})\end{array}$ & $\begin{array}{c}\text { Yogurt sinbiotik pisang } \\
\text { Rerata } \pm \mathbf{S B} \\
(\mathbf{m g} / \mathbf{d l})\end{array}$ & $\mathbf{p}^{2}$ & $\begin{array}{c}\Delta \text { Perubahan } \\
(\mathbf{m g} / \mathbf{d l})\end{array}$ & $\mathbf{p}^{\mathbf{3}}$ \\
\hline $\mathrm{K}$ & 6 & $129,69 \pm 2,60$ & $134,01 \pm 2,63$ & 0,009 & $4,33 \pm 2,53(3,35 \%)$ & \\
$\mathrm{P} 1$ & 6 & $128,23 \pm 1,86$ & $100,15 \pm 5,16$ & 0,000 & $-28,07 \pm 6,12(-21,86 \%)$ & 0,001 \\
$\mathrm{P} 2$ & 6 & $130,01 \pm 2,32$ & $83,18 \pm 2,62$ & 0,000 & $-46,83 \pm 3,22(-37,31 \%)$ & \\
\hline
\end{tabular}

${ }^{1} \mathrm{HFFD}=$ high fat fructose diet; ${ }^{2}$ paired $t$-test $;{ }^{3}$ Kruskal Wallis

Tabel 4. Rerata kadar insulin sebelum dan sesudah pemberian yogurt sinbiotik pisang tanduk

\begin{tabular}{ccccccc}
\hline Kelompok & $\mathbf{n}$ & $\begin{array}{c}\text { HFFD }^{\mathbf{1}} \\
\text { Rerata } \pm \text { SB } \\
(\mathbf{m g} / \mathbf{d l})\end{array}$ & $\begin{array}{c}\text { Yogurt sinbiotik pisang } \\
\text { Rerata } \pm \mathbf{S B} \\
(\mathbf{m g} / \mathbf{d l})\end{array}$ & $\mathbf{p}^{2}$ & $\begin{array}{c}\Delta \text { Perubahan } \\
(\mathbf{m g} / \mathbf{d l})\end{array}$ & $\mathbf{p}^{3}$ \\
\hline $\mathrm{K}$ & 6 & $15,58 \pm 0,88$ & $18,76 \pm 0,94$ & 0,001 & $3,18 \pm 1,00(20,62 \%)$ & \\
$\mathrm{P} 1$ & 6 & $16,00 \pm 1,50$ & $13,33 \pm 1,97$ & 0,054 & $-2,68 \pm 2,61(-16,04 \%)$ & 0,000 \\
$\mathrm{P} 2$ & 6 & $16,31 \pm 0,97$ & $8,93 \pm 1,38$ & 0,000 & $-7,37 \pm 1,43(-45,17 \%)$ & \\
\hline
\end{tabular}

${ }^{1} \mathrm{HFFD}=$ high fat fructose diet; ${ }^{2}$ paired $t$-test $;{ }^{3}$ One-way ANOVA

peningkatan rerata kadar glukosa darah secara signifikan $(\mathrm{p}<0,05)$. Tidak terdapat perbedaan kadar glukosa darah antara kelompok kontrol, kelompok perlakuan 1, dan kelompok perlakuan $2(\mathrm{p}>0,05)$ setelah diberikan pakan tinggi lemak tinggi fruktosa berdasarkan hasil uji Oneway ANOVA.

Pengaruh pemberian yogurt sinbiotik pisang tanduk terhadap kadar glukosa darah

Rerata kadar glukosa darah puasa pada kelompok perlakuan 1 dan kelompok perlakuan 2 mengalami penurunan yang bermakna setelah pemberian yogurt sinbiotik pisang tanduk $(\mathrm{p}<0,05)$. Sementara pada kelompok kontrol yang tidak diberi yogurt sinbiotik tepung pisang tanduk mengalami peningkatan kadar glukosa darah. Terdapat perbedaan kadar glukosa darah tikus antarkelompok setelah pemberian yogurt sinbiotik tepung pisang tanduk berdasarkan uji Kruskal Wallis. Kelompok perlakuan 2 mengalami penurunan rerata kadar glukosa darah terbesar yaitu $-46,83 \pm 3,22$ $(-37,31 \%)$ (Tabel 3).

\section{Pengaruh pemberian yogurt sinbiotik pisang tanduk terhadap kadar insulin}

Hasil analisis paired t-test menunjukkan adanya perbedaan rerata kadar insulin sebelum dan sesudah pemberian yogurt sinbiotik pisang tanduk pada kelompok perlakuan 2. Artinya, terjadi penurunan kadar insulin secara signifikan pada kelompok perlakuan 2 sesudah pemberian yogurt sinbiotik tepung pisang tanduk $(\mathrm{p}<0,05)$. Pada kelompok perlakuan 1 terjadi penurunan rerata kadar insulin tetapi secara statistik tidak signifikan $(p>0,05)$. Sementara pada kelompok kontrol terjadi peningkatan rerata kadar insulin selama perlakuan. Selisih rerata kadar insulin sebelum dan sesudah pemberian yogurt sinbiotik tepung pisang tanduk antarkelompok berdasarkan hasil analisis uji One-way ANOVA didapatkan hasil bahwa terdapat perbedaan kadar insulin tikus antarkelompok $(\mathrm{p}<0,05)$. Penurunan rerata kadar insulin terbesar terjadi pada kelompok perlakuan 2 yaitu $-7,37 \pm 1,43(45,17 \%)$ (Tabel 4).

\section{BAHASAN}

Hasil pengkondisian tikus menjadi sindrom metabolik menunjukkan pemberian pakan tinggi lemak tinggi fruktosa selama 2 minggu menyebabkan tikus percobaan mengalami hiperglikemia (rerata kadar glukosa darah puasa 129,31 $\pm 0,54 \mathrm{mg} / \mathrm{dl}$ ), hipertrigliseridemia (rerata kadar trigliserida 145,32 $\pm 3,82 \mathrm{mg} / \mathrm{dl}$ ), dan penurunan kadar kolesterol HDL (rerata kadar HDL 25,10 \pm 1,65 mg/dl) sehingga kondisi sindrom metabolik telah tercapai (1). Hasil penelitian ini 
menunjukkan adanya peningkatan rerata kadar glukosa darah pada semua kelompok setelah pemberian pakan HFFD selama 2 minggu. Berdasarkan hasil uji One-way ANOVA tidak terdapat perbedaan rerata kadar glukosa darah antarkelompok setelah diberikan pakan HFFD yang artinya rerata kadar glukosa darah puasa antarkelompok sebelum pemberian yogurt sinbiotik pisang tanduk adalah homogen. Kondisi hiperglikemia ini menunjukkan tikus mengalami kondisi prediabetes karena peningkatan kadar glukosa darah puasa di atas normal tetapi belum mengalami kondisi diabetes mellitus yang terjadi bila kadar glukosa darah puasa tikus wistar lebih dari atau sama dengan 7,8 mmol/L (> $140 \mathrm{mg} / \mathrm{dl}$ ) (20).

Hasil pengkondisian sindrom metabolik ini sesuai penelitian yang dilakukan di Italia pada tikus percobaan bahwa pemberian diet tinggi lemak tinggi fruktosa selama 2 minggu pada tikus menyebabkan terjadi peningkatan kadar glukosa darah, kadar insulin, gangguan profil lipid, dan memicu perlemakan hati (21). Penelitian ini juga sesuai dengan penelitian yang dilakukan di Sukoharjo bahwa pemberian pakan tinggi lemak tinggi fruktosa dapat meningkatkan kadar kolesterol total, kadar trigliserida, dan menurunkan kadar HDL tikus setelah 2 minggu pemberian (18). Kelebihan asupan fruktosa di hati akan dimetabolisme menjadi lemak. Fruktosa dapat menyebabkan kegagalan sinyal insulin sehingga dapat menurunkan sintesis glikogen dan meningkatkan glukoneogenesis, akibatnya terjadi peningkatan kadar glukosa darah (22). Pemberian pakan tinggi lemak pada tikus semakin meningkatkan kadar lemak di dalam darah. Tingginya kadar lemak di dalam darah dapat menurunkan kemampuan reseptor insulin dan menyebabkan ekspresi glucose transporter type 4 (GLUT 4) menurun. Penurunan ekspresi GLUT 4 menyebabkan transportasi glukosa ke dalam membran sel terganggu sehingga aktivitas pengangkutan glukosa menurun. Hal ini mengakibatkan kadar glukosa dalam darah meningkat $(22,23)$.

Lebih lanjut, hasil penelitian ini menunjukkan bahwa rerata kadar glukosa darah puasa pada kelompok perlakuan 1 dan kelompok perlakuan 2 mengalami penurunan yang bermakna setelah pemberian yogurt sinbiotik pisang tanduk $(\mathrm{p}<0,05)$. Hasil penelitian ini sesuai dengan penelitian mengenai pemberian yogurt probiotik yang dilakukan selama 6 minggu di India bahwa bakteri probiotik Lactobacillus dalam yogurt dapat menurunkan kadar glukosa darah sebanyak 26\% dan kadar insulin $36 \%$ pada tikus yang diinduksi pakan tinggi fruktosa dibandingkan kontrol (24). Hasil penelitian ini juga sejalan dengan penelitian yang dilakukan di Brazil pada penderita diabetes mellitus dengan pemberian minuman sinbiotik sebanyak $200 \mathrm{ml}$ yang mengandung Lactobacillus acidophilus, Bifidobacterium bifidum, dan FOS dapat menurunkan kadar glukosa darah sebesar $38 \%$ selama 30 hari (12). Apabila dibandingkan dengan penelitian sebelumnya, pemberian yogurt sinbiotik pisang tanduk ini lebih cepat dalam menurunkan kadar glukosa darah yaitu sebesar $37,31 \%$ selama 2 minggu pada tikus sindrom metabolik. Pemberian yogurt sinbiotik pisang tanduk dalam penelitian ini diberikan melalui sonde lambung sehingga dosis perlakuan yang diberikan dapat diasup seluruhnya oleh tikus. Pemberian yogurt sinbiotik pisang tanduk lebih efektif dalam menurunkan kadar glukosa darah diduga karena adanya peran antioksidan dalam pisang tanduk yang ditambahkan ke dalam yogurt ini. Antioksidan menangkap radikal bebas dan mengurangi peradangan dengan menekan produksi TNF- $\alpha$. Penurunan produksi TNF- $\alpha$ dapat meningkatkan sensitivitas insulin melalui peningkatan autofosforilasi dari reseptor insulin, peningkatan aktivitas tyrosine kinase pada reseptor insulin, dan peningkatan ekspresi GLUT-4. Ekspresi GLUT-4 yang meningkat menyebabkan pengangkutan glukosa darah ke membran sel meningkat dan kadar glukosa dalam darah menurun $(25,26)$. Bakteri Lactobacillus dalam yogurt dapat membantu memelihara mikrobiota usus. Efek ini menghambat transfer endotoksin bakteri ke dalam aliran darah dan mengurangi lipopolisakarida dan sitokin proinflamasi yang beredar, yang pada gilirannya menurunkan peradangan sehingga resistensi insulin menurun dan kadar glukosa darah dapat terkontrol (13).

Di samping itu, serat pangan pada yogurt sinbiotik pisang tanduk dapat menurunkan waktu transit makanan dalam usus halus dengan menyerap cairan dan membentuk gel di lambung yang dapat menghambat pengosongan lambung dan meningkatkan massa feses serta dapat difermentasi oleh mikroflora dalam usus besar. Serat pangan menghambat penyerapan glukosa di dalam pencernaan sehingga peningkatan kadar glukosa darah 
dapat ditekan (11). Kandungan serat pangan fungsional dalam yogurt sinbiotik pisang tanduk yaitu FOS sebagai prebiotik tidak dihidrolisis oleh enzim endogen dalam usus kecil dan dapat mencapai usus besar dalam bentuk utuh, kemudian mengalami fermentasi oleh mikroflora kolon. Fermentasi ini menghasilkan asam propionat yang merupakan senyawa utama asam lemak rantai pendek yang berperan dalam metabolisme glukosa (14). Asam propionat dimetabolisme di dalam hati dan memiliki kemampuan dalam menghambat glukoneogenesis. Mekanisme ini melalui kemampuan asam lemak rantai pendek dalam meningkatkan aktivitas enzim adenosine monophosphate-activated protein kinase (AMPK) di jaringan hati dan otot. Aktivasi jalur AMPK di hati menurunkan ekspresi gen glukoneogenik dari enzim glukosa 6-fosfatase dan fosfoenolpiruvat carboxykinase tetapi sejauh mana mekanisme asam lemak rantai pendek mengaktifkan AMPK belum diketahui secara jelas (15).

Hasil penelitian ini menunjukkan rerata kadar insulin puasa tikus setelah pengkondisian sindrom metabolik pada kelompok kontrol yaitu 15,58 $\pm 0,88$ $\mu \mathrm{U} / \mathrm{ml}$; kelompok perlakuan 1 yaitu $16,00 \pm 1,5 \mu \mathrm{U} / \mathrm{ml}$; dan kelompok perlakuan 2 yaitu 16,31 $\pm 0,97 \mu \mathrm{U} / \mathrm{ml}$. Rerata kadar insulin puasa semua kelompok sebelum perlakuan yogurt sinbiotik pisang tanduk melebihi $5 \mu \mathrm{U} /$ $\mathrm{ml}$. Ketika kadar insulin puasa lebih dari $5 \mu \mathrm{U} / \mathrm{ml}$ dapat mengindikasikan adanya masalah metabolisme seperti prediabetes yang dapat meningkatkan risiko penyakit degeneratif $(27,28)$. Insulin adalah hormon utama yang mengatur glukosa darah dan metabolisme lemak. Jumlah jaringan lemak viseral yang meningkat menyebabkan peningkatan lipolisis sehingga terbentuk asam lemak bebas dalam jumlah yang lebih banyak dibandingkan dengan kebutuhan. Asam lemak bebas yang berlebihan menghambat degradasi insulin di hati, akibatnya terjadi hiperinsulinemia sebagai respons tubuh untuk menjaga kadar glukosa darah tetap normal (23). Penelitian ini akan lebih lengkap bila dilakukan pemeriksaan kadar insulin awal tikus sehingga dapat diketahui kadar insulin awal sebelum tikus mengalami sindrom metabolik.

Kelompok perlakuan 2 dengan dosis pemberian yogurt sinbiotik pisang tanduk sebesar $0,018 \mathrm{ml} / \mathrm{hari}$ / grBB tikus mengalami penurunan rerata kadar insulin terbanyak yaitu $-7,37 \pm 1,43(-45,17 \%)$. Kelompok perlakuan 1 juga mengalami penurunan rerata kadar insulin meskipun secara statistik tidak bermakna ( $p>0,05$ ). Kelompok kontrol yang tidak diberi yogurt sinbiotik tepung pisang tanduk mengalami peningkatan rerata kadar insulin. Hal ini bisa disebabkan kondisi hiperinsulinemia yang semakin meningkat sebagai kompensasi dari kadar glukosa darah yang terus meningkat selama penelitian.

Insulin diproduksi oleh sel $\beta$ pankreas, pengeluaran insulin dipengaruhi oleh level glukosa darah (29). Kandungan serat pangan dalam yogurt sinbotik pisang tanduk dapat menghambat penyerapan glukosa di dalam pencernaan sehingga peningkatan kadar glukosa darah dapat ditekan (11). Tidak hanya serat pangan, adanya antioksidan dalam yogurt dapat menurunkan resistensi insulin dengan menangkap radikal bebas dan mengurangi peradangan sehingga ekspresi GLUT-4 meningkat yang pada akhirnya menurunkan kadar glukosa darah (24). Penurunan kadar glukosa darah secara perlahan menyebabkan penurunan kebutuhan insulin. Kadar glukosa darah sebanding dengan jumlah insulin yang dibutuhkan sehingga jika peningkatan kadar glukosa darah dapat ditekan maka produksi insulin akan menurun (11).

\section{SIMPULAN DAN SARAN}

Pemberian yogurt sinbiotik pisang tanduk dapat menurunkan kadar glukosa darah dan kadar insulin pada tikus sindrom metabolik dengan penurunan terbesar pada dosis $0,018 \mathrm{ml} /$ gramBB tikus/hari. Penelitian ini tidak dilakukan uji kandungan zat gizi dan fitokimia seluruhnya dalam yogurt sinbiotik pisang tanduk sehingga diharapkan peneliti selanjutnya dapat melakukan uji kandungan zat gizi dan fitokimia seluruhnya dalam yogurt sinbiotik pisang tanduk. Perlu penelitian lebih lanjut pada hewan coba mengenai pemberian yogurt sinbiotik pisang tanduk terhadap kadar insulin pada kondisi diabetes mellitus kronis yang produksi insulinnya berkurang.

\section{Pernyataan konflik kepentingan}

Penulis menyatakan tidak ada konflik kepentingan dengan pihak-pihak yang terkait dalam penelitian ini. 


\section{RUJUKAN}

1. National Cholesterol Education Program (NCEP) Expert Panel on Detection, Evaluation, and Treatment of High Blood Cholesterol in Adults (Adult Treatment Panel III). Third report of the national cholesterol education program (NCEP) expert panel on detection, evaluation, and treatment of high blood cholesterol in adults (adult treatment panel III) final report. Circulation 2002;106:3143-421.

2. International Diabetes Federation. The IDF consensus worldwide definition of the metabolic syndrome. [series online] 2006 [cited 2017 Januari]. Available from: URL: http://www. Idf .org.

3. Nelms M, Sucher K, Lacey K, Roth S. Nutrition therapy and phatophysiology. In: Cosio Y, ed. Cengage Learning. Inc. Second edition. California, USA: Brooks/Cole Cengage Lerning; 2010.

4. Yin Q, Chen X, Li L, Zhou R, Huang J, Yang D. Apolipoprotein B/apolipoprotein A1 ratio is a good predictive marker of metabolic syndrome and premetabolic syndrome in Chinese adolescent women with polycystic ovary syndrome. J Obstet Gynaecol Res 2013;39(1):203-9.

5. Rolfes S, Pinna K, Ellie W. Diabetes melitus. In: Understanding normal and clinical nutrition. Eighth. California, USA: Brooks/Cole Cengage Lerning; 2009.

6. Shaghaghi M, Pourahmad R, Adeli H. Synbiotic yogurt production by using prebiotic compounds and probiotic lactobacilli. Intl Res J Appl Basic Sci 2013;5(7):839-46.

7. Nikjooy S, Hashemi S. Study the possibility of producing symbiotic yogurt containing lactobacillus casei and wild thyme extract. Intl J Agri Crop Sci 2015;8(1):61-7.

8. Standar Nasional Indonesia. Yogurt. ICS 67.100.10. SNI 2981; 2009.

9. Jenie B, Widowati S, Nurjanah S. Pengembangan produk tepung pisang dengan indeks glikemik rendah dan sifat prebiotik sebagai bahan pangan fungsional. Jurnal Teknologi dan Ilmu Pangan Institut Pertanian Bogor 2009;1-31.

10. Karlina R, Rahayuni A. Potensi yoghurt tanpa lemak dengan penambahan tepung pisang dan tepung gembili sebagai alternatif menurunkan kolesterol. Journal of Nutrition College 2013;3(2):16-25.

11. Nadimin, Sri D, Sadariah. Pengaruh pemberian diit tinggi serat terhadap penurunan kadar gula darah pasien DM tipe-II di RSUD Salewang Kab. Maros. Media Gizi Pangan 2009; VII(1):1-5.

12. Moroti C, Magri L, Costa M, Cavallini D, Sivier K. Effect of the consumption of a new symbiotic shake on glycemia and cholesterol levels in elderly people with type 2 diabetes mellitus. Lipids Health Dis 2012;11:29.
13. Laitinen K, Poussa T, Isolauri E. Nutrition, Allergy, mucosal immunology and intestinal microbiota group. probiotics and dietary counselling contribute to glucose regulation during and after pregnancy: a randomised controlled trial. Br J Nutr 2009;101(11):1679-87.

14. Slavin J. Fiber and prebiotics: mechanisms and health benefits. Nutrients 2013;5:1417-35.

15. Besten G, Eunen K, Groen A, Venema K, Reijngoud D, Bakker B. The role of short-chain fatty acids in the interplay between diet, gut microbiota, and host energy metabolism. J Lipid Res 2013;54:2325-40.

16. Octavia ZF, Djamiatun K, Suci N. Pengaruh pemberian yogurt sinbiotik tepung pisang tanduk terhadap profil lipid tikus sindrom metabolik. Jurnal Gizi Klinik Indonesia 2017;13(4):159-69.

17. World Health Organization (WHO). General guidelines for metodologies on research and evaluation of traditional medicine. Geneva: WHO; 2001.

18. Muflikhatur S, Murwani H. Perbedaan pengaruh antara ekstrak dan rebusan daun salam (Eugenia polyantha) dalam pencegahan peningkatan kadar kolesterol total pada tikus Sprague Dawley. Journal of Nutrition College 2014;3(1):142-9.

19. Ratnawati H, Widowati W. Anticholesterol activity of velvet bean (Mucuna Pruriens L.) towards hypercholesterolemic rats. Sains Malaysiana 2011;40(4):317-21.

20. Zhang M, Lv X, Li J, Xu Z, Chen L. The characterization of high-fat diet and multiple low-dose streptozotocin induced type 2 diabetes rat model. Exp Diabetes Res 2008;23:1-9.

21. Crescenzo R, Bianco F, Coppola P, Mazzoli A, Tussellino $\mathrm{M}$, Carotenuto R, et al. Fructose supplementation worsens the deleterious effects of short-term high-fat feeding on hepatic steatosis and lipid metabolism in adult rats. Exp Physiol 2014;99(9):1203-13.

22. Warditiani N. Uji aktivitas antihiperlipidemia dan antiaterosklerosis isolat andrografolid dan ekstrak terpurifikasi herba sambiloto (Andrographis paniculata (Burm.f) Ness) pada tikus diabetes mellitus tipe 2 resistensi insulin [Tesis].Yogyakarta: Fakultas Farmasi Universitas Gadjah Mada; 2012.

23. Bender D. Energy nutrition-the metabolism of carbohydrates and fats. In: Bender DA, editor. Introduction to nutrition and metabolism. Fourth ed. Boca Raton: CRC Press; 2008.

24. Yadav H, Jain S, Sinha P. Antidiabetic effect of probiotic dahi containing Lactobacillus acidophilus and Lactobacillus casei in high fructose fed rats. Nutrition 2007;23(1):62-8. 
25. Hajiaghaalipour F, Khalilpourfarshbafi M, Arya A. Modulation of glucose transporter protein by dietary flavonoids in type 2 diabetes mellitus. Int J Biol Sci 2015;11(5):508-24.

26. Widowati W. Potensi antioksidan sebagai antidiabetes. JKM 2008;7(2):1-11.

27. Sinatra S, Simpson G. "Fire in the heart": new developments in diagnosis, prevention \& treatment of cardiovascular disease. Chapter 4. [series online] 2004 [cited 2017
Januari]. Available from: URL: http://www.a4m.com/ assets/pdf/bookstore/thera6_ch4.pdf?SESSION_MAIN

28. Muniyappa R, Lee S, Chen H, Quon MJ. Current approaches for assessing insulin sensitivity and resistance in vivo: advantages, limitations, and appropriate usage. Am J Physiol Endocrinol Metab 2008;294(1):E15-26.

29. Aronoff S, Berkowitz K, Shreiner B, Want L. Glucose metabolism and regulation: beyond insulin and glucagon. Diabetes Spectrum 2004;17(3):183-90. 